\title{
AN ANALYSIS OF THE CONFORMITY OF REGIONAL ECONOMIC INTEGRATIONS WITH ARTICLE XXIV OF GATT
}

\author{
Mehmet Sait AKMAN*
}

Regional arrangements or so-called free trade areas and customs unions have proliferated among states. Today, most of the Contracting Parties to the GATT are simultaneously members of a customs union or of a free-trade area. One may argue why such regional groupings are allowed to be established under the GATT system, notwithstanding the cornerstone of the GATT's commitment to non-discrimination toward third countries and the most fovoured nation principle as laid down in Article I. As is clear form its wording, Article I(1) GATT requires that "... any advantage, favor, privilege and immunity granted by any contracting party to any product ... shall be accorded immediately and unconditionally to the like product of all contracting parties". However, Article XXIV, as far as free trade areas and customs unions are concerned, allows an exception to the very basic principle of the General Agreement.

There are various arguments that Article XXIV is directly contradictory to the GATT spirit. So, why has such an exception been justified in the General Agreement although this may lead to circumvention from its basic rules? Of course, the answer to this question should be related to economic arguments. The unilateral tariff reductions among contracting parties are believed to be the best way for the liberalisation of world trade within the framework of GATT. However, this is not an easy thing to achieve in practice. Regional economic integration, on the other hand, does not serve to create a completely free international trade, but at least it is a move towards it. ${ }^{1}$ In other words, such groupings (i. e. customs unions) may not be the best but are second-best solutions for achieving a free international trade and maximizing welfare. ${ }^{2}$

* Research Assistant, Marmara University EC Institute

1 Nevin, E., The Economics of Europe, London, Macmillan, 1990, pp. 61-62.

2 The theory of "second-best" was first examined by Jacob Viner who in his famous book "The Customs Union Issue" argued that entry into a customs union may raise a country's economic welfare, but it may also reduce it (trade diversion $v$. trade creation). 
This belief was reflected in the text of the General Agreement by its drafters. It was the outcome of a French proposal during the Havana Conference "to increase freedom of trade by encouraging the development of greater economic unity throughout areas more extensive than those defined by political frontiers". ${ }^{3}$

Paragraph 4 of Article XXIV set forth the basic rule that:

"The contracting parties recognize the desirability of increasing freedom of trade by the development, through voluntary agreements, of closer integration between the economies of the contracting parties to such agreements."

However, the question is obvious: On the one hand the drafters of the General Agreement have foreseen the desire for such integrations while on the other this produced a conflict with the two basic requirements of the GATT: The promotion of free trade through multilateral tariff negotiations and most-favoured-nation principle since free trade areas and customs unions involve discriminatory application against the non-member countries.

As the primary purpose of customs unions is to shift sources of supply from the higher-cost domestic producers to those, in the other member states having lower costs, it definitely has a "trade-creating" effect. Nevertheless, the problem begins here that lower-cost member state producers may be (as a consequence of facing no tariffs) preferred to the producers of non-member countries no matter how much lower the latter's costs are. Then, customs unions have also "trade diverting" effects as well.

Viner argued that "customs unions are more likely to operate in the freetrade direction". ${ }^{4}$ However, he also proposed that they can only be so if they are more "trade creating" than "trade diverting". Professor Dam goes further in classifying them as production and consumption effects. ${ }^{5}$ Accordingly, production effects are favourable if low-cost member country products are preferred to high-cost domestic ones, whereas they are unfavourable in case of the replacement of high-cost member country goods for low-cost non-member goods. From this deduction it is easy to estimate that the former

3 Haight, F. A., "Customs Unions and Free Trade Areas under GATT" 6 Journal of World Trade Law, 1972, pp. 395-396.

4 Viner, Jacob, The Customs Union Issue, London, Stevens \& Sons Ltd, 1950, pp. 52-53.

5 Dam, Kenneth W., "Regional Economic Arrangements and the GATT: The Legacy of a Misconception", 4 Universtiy of Chicago Law Review, Vol. 30, Summer 1963, pp. 625-29. 
constitute a movement toward free trade whereas the latter proceeds in the opposite direction.

These arguments are observed in the criteria laid down in the second phrase of paragraph 4:

"They (contracting parties) also recognise that the purpose of a customs union or of a free trade area should be to facilitate trade between the constituent territories and not to raise barriers to the trade of other contracting parties with such territories".

In order to achieve this aim the following paragraphs (paras. 5-9) set out the criteria. Accordingly, paragraph 5 stipulates that the formation of a customs union or of a free trade area or the adoption of an interim agreement necessary for the formation of a customs union or of a tree trade area is allowed by the provisions of the General Agreement provided that:

"(a) with respect to a customs union, or an interim agreement leading to the formation of a customs union, the duties and other regulation of commerce ... shall not on the whole be higher or more restrictive than the general incidence of the duties and regulations of commerce applicable in the constituent territories prior to the formation of such union or the adoption of such interim agreement, as the case may be; ${ }^{6}$

(b) with respect to a free trade area, or an interim agreement leading to the formation of a free trade area, the duties and other regulatons of commerce ... shall not be higher or more restrictive than the corresponding duties and other regulations of commerce existing in the same constituent territories prior to the formation of the free trade area, or interim agreement, as the case may be; $;$ and

(c) any interim agreement ... shall include a plan and a schedule for the formation of such a customs union or of such a free trade area within a reasonable length of time." 8

6 Art. XXIV, para. 5 (a).

7 Art. XXIV, para. 5 (b)

8 Art. XXIV, para. 5 (c). 
The basic questions that arise form the wording and spirit of Article XXIV may be:

- $\quad$ to what extent are paragraphs 4 and 5-9 interrelated; in other words, if an agreement is not inconsistent with paragraph 4 , does this necessarily mean that it also meets the criteria laid down under paragraphs 5-9? and

- will a customs union which complies with the requirements in Article XXIV, but is more trade diverting than trade creating, be consistent with the General Agreement??

- more importantly, is it possible to facilitate trade without raising any barriers to the trade of non-members?

Paragraph 4 implies that it was added to the GATT as a general introductory provision through the advocacy of parties willing to take part in a regional arrangement. This considerable exception could, without doubt, be abused by most of the contracting parties unless supported by certain substantive rules. The word "acordingly" is crucial in the sense that paragraphs 5-9 have a complementary nature. As far as the purpose of a customs union or of a free trade area is not to raise barriers to the trade of non-members, paragraph 4 is open to ambiguity.

Professor Dam suggests that "trade creation" is the necessary and sufficient standard for the authorization of such arrangements under GATT. ${ }^{10}$ However, when the outcome of a customs union or of a free trade area on non-members is concerned, and considering that the criteria under Article XXIV of GATT deals only with the removal of internal barriers and the incidence of common external tariffs and regulations of commerce, it would be beyond the jurisdiction of GATT to measure the effects of indirect regulations other than those mentioned in paragraph 5, although the former may lead the regional arrangement to be more trade diverting, on balance, notwithstanding its compliance with the criteria in Article XXIV. ${ }^{11}$ In that case, should the Contracting Parties approve such a trade diverting one or seek for a further standard which may, of course, be challenged that it is beyond the requirements of Article XXIV?

9 Allen, James J., The European Common Market and the GATT, Washington D.C., The University Press, 1960, p. 28.

10 Jackson, John, World Trade and the Law of GATT: A Legal Analysis of the General Agreement on Tariffs and Trade, Indianapolis, Bobbs-Merrill, 1969, pp. 600-602.

11 Allen, op. ct., pp. 225-226. 
The difficulty and ambiguity found in the criteria for permissible regional arrangements might be a reason for the high degree of tolerance by the contracting parties for most of the regional arrangements.

\section{Examination of Criteria under Article XXIV}

A possible reason of approval of nearly all the arrangements before the Contracting Parties may be attributed to the fact that almost all of them were brought to GATT as an interim agreement which is automatically given a reasonable length of time to complete its formation. It is not surprising for this reason that no regional interim arrangement is inconsistent with GATT at the outset. In other words, "there is no prerequisite of approval for an interim agreement" and contracting parties must initiate a disapproval through recommendations to the parties to the agreement. ${ }^{12}$ The parties concerned are allowed a "reasonable" time limit to eliminate duties and other restrictive regulations of commerce between themselves which probably direct contracting parties to make no recommendations "at this juncture". However, the problem so far arising relates to the length of "reasonable" time. In the Association Agreement between Turkey and the European Economic Community the time period proposed for the formation of a customs union was 22 years. Further, the decision whether to proceed with the formation of the union would be subject to the unanimous approval of the parties to the agreement at the end of the preparatory stage, having regard to the economic situation of Turkey. Therefore, some members of the Working Party were of the opinion that the Agreement could not be considered to constitute a plan and schedule leading to the formation of a customs union "within a reasonable length of time" as required in Article XXIV ${ }^{13}$. However, the Contracting Parties did not disapprove the Agreement. In the New Zealand-Australia Free Trade Agreement (NAFTA) it was argued that it did not specify a time period for the free trade area to be completed as is required under Article XXIV, 5(c). This situation was actually causing the Agreement to remain in the interim stage for an indefinite period. ${ }^{14}$ Furthermore, Article 4 of the Agreement set out a plan and a schedule for the formation of a free trade area only for products which accounted for about 50 percent of the trade between the two par-

12 Jackson, op.cit., pp. 604-605.

13 GATT, Basic Instruments and Selected Documents, 1965, 13 th Supp., p. 61.

14 Thomas, D.J., "The GATT and the NAFTA Agreement", 15 Journal of Common Market Studies, 1976, p. 30. 
ties. This plan and schedule obviously did not conform with what is required in paragraph 5(c). Contracting Parties, hereupon, were content with inviting the parties to give serious consideration to preparing a comprehensive plan as soon as possible. ${ }^{15}$

The requirement in paragraph 5(c) for an interim agreement, of a plan and a schedule for the formation of a customs union or of a free trade area within a reasonable time limit was, without doubt, inserted to discourage the parties concerned in case of their attempt to illegally apply preferences to the benefit of other parties by abusing regional arrangements. This case has long been discussed in the association of overseas territories with the EEC. Also, the Agreement on Trade and Commercial Relations between Australia and Papua New Guinea (PACTRA) did not impose any obligation on the latter for reciprocal reduction of duties and other restrictive regulations of commerce, and even it did not provide a plan and a schedule. ${ }^{16}$ Nevertheless, it was not difficult for the parties to get a waiver through Article XXV: 5. The Contracting Parties found that the interim agreement of 1948 between Southern Rhodesia and the Union of South Africa neither had a timetable for the abolition of tariffs between the parties nor could the ten year period be considered a "reasonable time". Nonetheless, this interim agreement has also been approved by the Contracting Parties. They even did not consider whether the proposed agreement was a step towards free trade or not. ${ }^{17}$ Contracting Parties followed a tendency that "the plan and schedule need not necessarily be detailed and complete". ${ }^{18}$

Article XXIV: 8(a) and (b) requires that in the formation of a customs union or of a free trade area duties and other restrictive regulations of commerce are eliminated with respect to substantially all the trade between the constituent territories. The term "substantially" is one of the ambiguous words used in Article XXIV. It always created difficulty for the Contracting Parties to interpret what constitutes "substantially all" trade. Is 70 per cent a sufficient amount or should it be at least 98 per cent? Even if the general tendecy is to assume 70 per cent as substantial elimination, would it, then, be possible for the Contracting Parties to approve such arrangements leaving

15 GATT, Basic Instruments and Selected Documents, 1966, 14 th Supp., p. 22.

16 Huber, Jurgen, "The GATT Practice in Examing Regional Arrangeements under Article XXIV", 19 Jaurnal of Common Market Studies, 1981, p. 289.

17 GATT, Basic Instruments and Selected Documents, 1954, 3 rd Supp., p. 47.

18 GATT Basic Instruments and Selected Documents, 1965, 13th Supp., p. 62. 
major industries or trade in products forming the remaining 30 per cent outside the elimination scheme? What should be the reaction of the Contracting Parties in case of a free trade area through participation of three countries A, $\mathrm{B}$ and $\mathrm{C}$ and $\mathrm{A}-\mathrm{B}$ trade is a few times that of the trade between $\mathrm{A}$ or $\mathrm{B}$ on the one side and $C$ on the other, $C$ still keeps restrictions in trade while these restrictions between A and B were completely removed. Would Contracting Parties hesitate to approve this agreement? ${ }^{19}$

In practice no standard or a generally accepted level has been set out in the history of GATT. The Stockholm Convention establishing the European Free Trade Area does not apply to trade in agricultural goods, although it is to be assumed as a major economic sector that can never be set aside. As was pointed out in the Working Party report "substantially all the trade" had a qualitative as well as quantitative aspect and for this reason percentage of trade covered was not the only factor to be considered. ${ }^{20}$ On the other hand, member states were of the opinion that Contracting Parties should have taken into account the difference between "substantially all the trade" used in Article XXIV and "trade in substantially all the products". These two phrases do not seem to be too intransigent.

In the examinations of the Working Party, the Latin American Free Trade Agreement (LAFTA), it was observed that it not only omitted elimination of duties between the constituent territories in trade in agricultural goods, but the reductions were not linear. In fact, LAFTA was an attempt having unfavourable production effects that lead to misallocation of resources and trade diversion, since its primary aim was the industrialization of the member states. As Professor Jackson emphasised, the two goals, namely, the goal of proliferation of free trade and efficient allocation of world resources, and the goal of industrialization through preferential regional arrangements among the neighbouring countries, are inconsistent with each other. ${ }^{21}$ However, again not surprisingly, the Contracting Parties could not determine whether the Agreement provided a liberalization in "substantially all the trade", and even did not need to make recommendations under paragraph 7 (b) at this juncture.22

19 Jackson, op. cit., pp. 608-609.

20 GATT, Basic Instruments and Selected Documents, 1960, 9th Supp., pp. 70-87.

21 Jackson, op.cit., p. 621.

22 GATT, BISD,1960, 9th Supp., p. 87. 
In the case of NAFTA (New Zealand-Australia Free Trade Agreement) only a small portion of trade was covered for the establishment of a free trade area and no progress was clear in aggregate terms. The Agreement included only 60 per cent of the total trade between the two countries and about 90 per cent was already duty free. As to the justification by the Contracting Parties of it as a free trade area, its smaller coverage of trade may be of its inclusion of many types of commodities and total elimination of duties on them. The number of commodities included, on the other hand, does not mean that it eliminated tariffs with respect to "substantially all the trade". 23

Paragraph 8(a) and (b) not only stipulates the elimination of duties but also other restrictions of commerce with the exclusion, if necessary, of those permitted under Article XI, XII, XIII, XIV, XV and XX of GATT. If one interprets this as the abolition of quantitative restrictions against other member states only, would not it be discriminatory against non-members? Article XII of the GATT prohibits non-discriminatory administration of quantitave restrictions. The disagreement, in the EFTA case, arose by the allegation of member countries to interpret Article XXIV as permitting them to remove the restrictions in the free trade area at a faster rate than against nonmembers. The other members in the Working Party opposed it, claiming that provisions of Article XXIV in no way affect the obligations of Contracting Parties entering a free trade area to apply restrictions in a discriminatory way. They based their argument on the fact that Article XIV forming exceptions to Article XIII did not provide exception for a customs union or a free trade area under Article XXIV. ${ }^{24}$

The same situation was on the agenda in LAFTA, NAFTA and Association of Greece with the EEC cases, but Contracting Parties were, in all these cases, far from solving this issue. If we make an analogy it is not difficult to claim that each customs territory or free trade area should be treated as a single contracting party to which all the provisions and surely obligations of GATT apply. However, the assumption does not help us too much until the interim agreement attains its ultimate aim. A customs union or a free trade area may be entitled to escape clause exceptions but at the interim stage all the restrictive regulations of commerce, including certain measures such as antidumping, countervailing duties, safeguard measures and even govern-

23 Thomas, J., op. cit., pp. 33-39.

24 Dam, Kenneth W., The GATT Law and International Economic Organization, Chicago, University of Chicago Press, 1970, p. 280; see also Huber J., "The GATT Practice ...", 19 Journal of Common Market Studies, 1981, pp. 286-287. 
ment procurement regulations should be eliminated between members of the regional arrangement, since emergency restrictions (Art. XIX) and security exceptions (Art. XXI) are not excepted by Article XXIV: 8 (a) and (b).

Article XXIV: 5 (a) provides in the case of a customs union that duties and other regulations of commerce imposed at the institution of any such union or interim agreement in respect of trade with non-member Contracting Parties shall not on the whole be higher or more restrictive than the general incidence of those applicable in the constituent territories prior to the fromation of such union or the adoption of such interim agreement. A similar phrase is used in paragraph 5 (b) for free trade areas stipulating that the duties and other regulations of commerce "... maintained shall not be higher ... than the corresponding duties ... prior to the formation of the free trade area". This provision led the Contracting Parties into difficulty as to what is meant by the "general incidence". Consider, an interim agreement leading to a customs union between A and B, where A's general tariff level was 10 per cent and B's was 5 per cent previously. If the countries decide to form a common customs tariff by a simple mathematical average method without the volume of trade, the CCT would have an average of 7.5 per cent. However, if the total amount of products imported from third conutries were actually destined, mostly, to country having a lower level of tariff (in the example, B) prior to that agreement, the exporting Contracting Parties not parties to such agreement shall face a more restrictive situation ${ }^{25}$. In the case of common customs tariff of the EEC, some of the Contracting Parties in the Working Party severly criticized the application of mathematical average method of the Community. The draftsmen of GATT probably did foressee this and replaced the original phrase "average level" with "general incidence" which allows more flexibility so that the volume of trade may be taken into account. ${ }^{26}$ Although the EEC claims that Article XXIV: 5(a) does not lay down any particular method, the Working Party could not come to a solution, apparently due to political factors.

Another point of ambiguity again stemming from the wording of Article XXIV is the requirement that duties and other regulations imposed "at the institution" of any such union shall not on the whole be higher or more restrictive. However, the establishment of the European Economic Community for example had been brought in as an interim agreement containing a transi-

25 Accordingly, the Contracting Parties previously bearing a 5 per cent tariff on the average, will now be facing 7.5 per cent in their trade with country $B$.

26 Jackson, op.cti., pp. 611-612. 
tionary period of twelve years. Article XXIV: 5 (a) by stipulating "at the institution" seems to omit this fact, which may lead the union (i. e. EEC) to raise the tariffs or other restrictions at the time the common tariffs is imposed. This may be considered as raising the "general incidence" of tariffs and other regulations as long as they do not exceed a bound GATT rate. ${ }^{27}$

The term "on the whole" implies that the level of tariffs in respect of all categories of products under common external tariff should not be higher than the level of tariffs of the prior application of constituent territories. However, the previous level of tariffs applicable in the constituent territories may either be those actually applied to imports or the tariffs legally bound by GATT negotiations. If Article XXIV is interpreted in accordance with the former then the union could circumvent the obligation with regard to "not on the whole be higher or more restrictive" by raising the general level of duties successively.

To these ambiguities under Article XXIV may be added new ones when, for instance, an excise duty as an internal tax is imposed on a product which is entirely imported by the union or free trade area rather than produced domestically. Consequently, the internal tax, no matter what its aim is, would have the effect of a disguised barrier to trade. ${ }^{28}$ Contrary to what the EEC has argued, these internal taxes constitute a factor that should be taken into account in estimating the general incidence of duties and other regulations of commerce as long as there is discrimination between the imported and domestic products. Furthermore, paragraph 5 (a) should not be understood as allowing the application, by the members of a union, of a common level of quotas to products of states not parties to it. There must not be discrimination between the member or non-member contracting parties to a customs union, as far as the reduction of quantitative restrictions are concerned, unless the contrary is justified under Articles XI, XII, XIII and XIV of the GATT.

\section{Re-examining the Regional Arragements Clause of GATT}

So far, no regional arrangements notified to GATT have been disapproved, notwithstanding the fact that there was none which fully complied with the requirements set out under Article XXIV. ${ }^{29}$ Actually, the compli-

27 Ibid., pp. 615-616.

28 Allen, J., The European Common Market and the GATT, 1960, pp. 86-87.

29 The United Kingdom-Ireland FTA is an exception to this rule and can be considered as complatible with the GATT. 
ance of a particular regional arrangement to paragraphs 5-9 does not seem to be an obligation, since they may be allowed by the approval of Contracting Parties by two-thirds majority, even though they do not fully comply with the requirements of paragraphs 5-9 inclusive, provided that such proposals lead to the formation of a customs union or of a free trade area in the sense of this Article. ${ }^{30}$ This provision is essential in giving flexibility to those arrangements at the interim stage of prove themselves within a reasonable length of time. In fact, many of these arrangements were approved by invocation of it. Some other proposals were approved by a waiver under Article XXV: 5 since they were not properly considered under Article XXIV but which actually resembled some aspects of Article XXIV arrangements. For instance, the European Coal and Steel Community which covered only coal and steel, products clearly not substantially all the trade or the Trade Expansion and Economic Cooperation Agreement Between India, the United Arab Republic and Yugoslavia, signed in 1967, were granted a waiver. ${ }^{31}$

Even a regional arrangement such as LAFTA, having unfavourable production and trade diverting effects with no particular plan and a schedule was tolerated by the Contracting Parties. In practice, it was not so easy for a regional grouping to be disapproved by Contracting Parties. This can initially be attributed to a couple of reasons. First, Contracting Praties who are to evaluate the arrangement in a Working Party may also be members of a customs union or of a free trade area. Today more than two-thirds of the Contracting Parties are, in a way, members of such a union or an area. That means they cannot expect from an arrangement full compliance if they also are not in a different position vis-a-vis the requirements under ArticleXXIV. This situation constitutes political behaviour. Secondly, partly due to the first reason and partly because of the feeble structure of the General Agreement, no case law was created within GATT. Since no precedents were established no future criterion is applicable for the arrangements posing the same legal problems. ${ }^{32}$

However, the concealed facts lie on the misleading expectations from Article XXIV, and moreover on the weakness of the GATT system. So far,

30 Art. XXIV, para. 10.

31 For further information see Jackson, World Trade and the Law of GATT, 1969, pp. 592 599, and Schoth, Jeffrey J., More Free Trade Areas? Washington D.C., Institute for International Economics, May 1989, pp. 61-69.

32 Huber, J., op. cit., pp. 295-296. 
what Contracting Parties looked for has not been whether the regional integrations would serve to better allocation of world resources and whether more trade would be created, but just to be all attention on how the nonmembers would be affected adversely. This brings us to the fact that paragraph 4, requesting the regional grouping to facilitate trade and not to raise barriers to others, must be given primary emphasis, even if paragraphs 5-9 are fulfilled.

In order to remedy this malstructuring, a reinterpretation of Article XXIV is inevitable. As it is suggested many years ago, "the revision of standards of Article XXIV and extension of GATT consultation would be a useful step forward". ${ }^{33}$ Firstly, the information procedure should be strengthened and any refusal to supply the necessary information to the Contracting Parties as they may seem appropriate must be prevented. Secondly, the recommendations must be decisive. Thirdly, annual consultations should be made to scrutinize the progress of the arrangements, whether they are toward or away from free trade and the general principles of GATT. Fourthly, a product-by-product review rather than "on the whole" must be made. This would enable Contracting Parties to assess the degree of trade creation and trade diversion. ${ }^{34}$ Fifthly, working parties should be composed of independent experts rather than Contracting Parties. Only in this way can the decisions be far from political bias, and regional groupings greatly violating the most favoured nation principle may be condemned and dissapproved by Contracting Parties. ${ }^{35}$ Sixth, the present compensatory adjustment must be extended to discriminatory elimination of internal tariffs as well as common external tariff. Seventh, preferential arragements seem to be reducing the favourable effects of regional arrangements if substantially all the trade between the constituent territories is not liberalized. In this case, the association agreement of overseas territories with the EEC can be considered as discriminatory because the sheltered ACP countries will have a duty-free market for their exports while the non-members not so privileged will face a Commen External Tariff. This may be justified since such regional groupings are a basic exemption from the MFN clause of GATT. However,the proposed grouping, i.e. the customs union or the free trade area should be completed in a reason-

33 Dam, "The Legacy of Misconception", 1963, pp. 662-663.

34 Dam, GATT Law and International Econonic Organisation, 1970, p. 169.

35 Lortie, p., The Economic Integration and the Law of GATT, New York, Praeger Publ., 1975 , p. 169. 
able period and comprise "substantially all the trade" rather than a slight margin of products. This leads us to a strange fact that the discriminatory attitude is forbidden unless it is one hundred per cent effective.

At the free trade area and customs union levels of economic integrations, the possible economic gains can be the increased efficiency in production, better exploitation of economies of scale, better terms of trade, enhanced competitive position and advancement in technology and the quality of the factors of production. ${ }^{36}$ These aims may seem to fall beyond the purposes emphasized in paragraph 4 that is, increasing the freedom of trade and to facilitate it between the members by not raising barriers to the trade of other contracting parties with members of the union or the area. However, they serve to those in the preamble of the GATT: raising standards of living, ensuring full employment and steadily growing volume of real income and effective demand, developing the full use of the resources of the world and expanding the production and exchange of goods.

I think, when the drafters laid down the standards concerning regional arrangements in Article XXIV, they partly neglected the preamble which should be the basis for all GATT negotiations and all the regional arrangements should be examined as to whether they serve this objective or not.

36 El-Agraa, A. M., Economics of the European Community, Philip Allan, 3rd ed., 1990, p. 79. 


\section{REFERENCES}

1. Allen, J. J. (1960), The European Common Market and the GATT, The University Press of Washington D.C.

2. Castel, J.G. (1988), "Consistency of the 1988 Canada - U.S. Free Trade Agreement with Article XXIV of the GATT", in M. Gold and D. Brown (eds.), Trade Offs on Free Trade, Carswell.

3. Courage Van Lier, I.M, (1984), "Supervision within GATT, P. Van Dijk (ed.), Supervisory Mechanisms in International Economic Organisations

4. Dam, K.W. (1970), The GATT Law and International Economic Organization, Chicago, University of Chicago Press.

5. Dam, K. W. (1963), "Regional Economic Arrangements and the GATT: The Legacy of a Misconception", The University of Chicago Law Review, Vol. 30.

6. El-Agraa, A. M. (1990), The Economics of the European Community, 3 rd ed., Oxford, Philip Allen.

7. GATT, The Text of the General Agreement on Tariffs and Trade, Geneva.

8. GATT., Basic Instruments and Selected Documents, 3rd Supp. (1954), 9th Supp. (1960), 13th Supp. (1965), 14th Supp. (1966)

9. Haight, F.A. (1972), "Customs Unions and Free Trade Areas Under GATT" , Journal of World Trade Law, Vol. 6

10. Hilf, M., Francis, G.J. and Pettersman, E.U. (eds), (1986), The European Community and GATT, Deventer, Kluwer

11. Huber, J. (1981), "The GATT Practice in Examining Regional Arrangements under Article XXIV", Journal of Common Market Studies, Vol. 19

12. Jackson, J.H., (1969), World Trade and the Law of GATT: A Legal Analysis of the GATT, Indianapolis, Bobbs-Merrill.

13. Jakcson, J.H., and Davey, W.J. (1986), Legal Problems of International Economic Relations, St. Paul, Minn., West Publishing Co. 
14. Lortie, P. (1975), The Economic Integration and the Law of GATT, New York, Praeger

15. Nevin, E. (1990), The Economics of Europe, London, Macmillan

16. Schott, J. J. (1989), More Free Trade Areas? Washington D. C., Institute for International Economics, Policy Analysis in International Economics Series, Vol. 27.

17. Thomas, D.J. (1976), "The GATT and the NAFTA Agreement", Journal of Common Market Studies, Vol. 30.

18. Viner, J. (1950), The Customs Union Issue, London, Stevens \& Sons Ltd. 